\title{
The effects of GA and SA hormonal treatments on growth and flowering of African violets (Saintpaulia ionantha wendi.)
}

\author{
Mohammad Aslanpour ${ }^{1}$ *, Mahmoud Shoor ${ }^{2}$, Behnaz Ghalekahi ${ }^{3}$, \\ Ahmad Sharifi ${ }^{4}$, Mahdieh Kharrazi ${ }^{5}$ \\ ${ }^{1}$ Associate Professor of Horticultural Sciences, University of Raparin, ranya, Kurdestan, Region, Iraq \\ (correspondingauthor), \\ ${ }^{2}$ Associate Professor, Faculty of Agriculture, Ferdowsi University of Mashhad, \\ ${ }^{3}$ Graduated Master, Faculty of Agriculture, Mashhad University, \\ ${ }^{4}$ Assistant Professor, Mashhad Jihad University \\ ${ }^{5}$ Assistant Professor, Mashhad Jihad University \\ Aslanpour.mohammad@gmail.com \\ $00989143894348-00964751034174$
}

\begin{abstract}
Saintpaulia (African violet) is one of the most popular flowering houseplants that need proper cultivation context for optimal vegetative and reproductive growth. It has been proved that the application of supplementary fertilizers, suitable cultivation context and the use of hormonal treatments and artificial light, has been able to offer more favorable growth and flowering for most plants. For this purpose, five distinct experiments were done to investigate the factors affecting the growth and flowering of this plant.

Hormonal treatment includes gibberellic acid at 3 levels: $(0,50$ and $100 \mathrm{mg} / \mathrm{L})$ and salicylic acid at three levels: $(0,0.01$ and $0.1 \mu \mathrm{M})$. All experiments were executed as a factorial experiment in a completely randomized factorial design with 5 replications. Most of the measured traits were significantly affected by the treatments of these three experiments. Using salicylic acid compared to the application of gibberellic acid improved the growth and flowering indices in this plant.
\end{abstract}

Keywords: Soilless, Fertilizer, Hormone, Light

\section{Literature review}

\section{An overview of African violets}

African violet is one of the most popular potted and ornamental flowering plants with economic value in the United States. This plant also has a rosette growth habit and fluffy and egg-shaped leaves. The flowers of this plant are formedwith five round petals on short stalks. The petals are not fluffy on the surface but they are fluffy at the rear surface and on the edges. The color of the flowers is usually blue, pink, purple, blue-purple, colorless or almost white with cyme inflorescence. The flowers have two flags with bigrenal-shaped and yellow anthers. It hasshort and conical and emerged ovary and they have a long, ovoid-shaped fruit. This plant is day-neutral and its flowering is controlled by the temperature and intensity of the light (Dole, 1999).

\section{Different methods of African violet planting and reproduction}

Using seed as a reproduction method is used only for amendment units. At the commercial level, leaf cuttingis used. The best cuttings are taken from mature leaves of two-month-old plants. The length of the petiole should be 4 to 5 centimeters and it does not need rooting hormones. Nowadays tissue culture method is used to quickly increase new varieties or to produce shimmers that are not able to preserve their shimmers tissue through leaf cuttings (Dole and Wilkins, 2006).

\section{Soilless cultivation}

Soilless cultivation means that the plant executes a complete cycle of life and reproduction without root in its natural environment, soil. In the cultivation of plants outside of the soil, the plant root is fed by a mineral liquid medium called a nutrient solution. This nutrient solution of water and oxygen offer the essential mineral elements generally as ions from soluble salts to the plants. As a result, the hallmark of this new technology is root nutrition by nutritional solution and does not necessitate a solid support, and if any, should not have any nutritional role, and it should be chemically neutral and facilitate oxygenation to the root system and a solid support for the plant (Roustaee, 2002). 


\section{Using growth regulators to improve the physiology and morphology of plants}

Research has indicated that plant growth hormones,due to their role in the physiological activity of plant biochemical processes, are important factors in the plant production. To this end, gibberellic acid treatment,in high concentrations, strengthens leaf growth of some of the plants. Also flowering increases the number and weight of produced flowers. This hormone affects flower quality duringthe flowering period and promotes flowering time in plants (Arteca, 1950).

In line with salicylic acid, induction of flowering, growth, and development, ethylene synthesis, the effect of opening and closing the stomas and breathing are of the important roles of this hormone. In plants under stress, salicylic acid has a protective role and increases the resistance to stress in the desired plant (Arteca, 1950).

\section{Gibberellin}

Gibberellins are a group of plant growth materials that in terms of the structure have a skeletal of gibberellin. These substances stimulate cell division and elongation, and other adjustments procedures are made in a similar manner to gibberellic acid (Arteca, 1950).

GA3 was the first commercially available gibberellin. This mixturehas been historically called gibberellic acid and has been used as a standard index in bioassay systems, and for this reason,the construction formula of this compound represents more than 90 known types of gibberellin today (Arteca, 1950).

\section{Using gibberellin on the growth and flowering quality of plants in different investigations}

In the field of floriculture, some producers believe that using GA is really important to improve plant phenotypic properties. Gibberellin has been used as an alternative to cold treatment in species such as Hyacinthus Liatris, Muscari, Iris, Lilium, and Tulipa. Although this hormone has been able to flower stimulation in these plants, its yield is lower than low-temperature treatment, especially for tulip species (Cardos et al., 2010).

In a study by Ramdevputra et al. (2009) in line with the effect of gibberellin hormone on Tagetes erectagrowth and flowering from four concentrations of this hormone: $0,100,200$ and $300 \mathrm{mg} / \mathrm{L}$, foliar application was done two times: 30 days after the transfer to the pot and about 15 days after the first time in the afternoon on the leaves and the terminal meristems of the plant.The results revealed that the highest fresh weight of the plant $(375.85 \mathrm{~g})$ was obtained in the treatment of $300 \mathrm{mg} / \mathrm{L}$ of gibberellin hormone, and following that, the highest fresh weight of the plant was in treatments of 200 and $100 \mathrm{mg} / \mathrm{L}$ of the hormone. The maximum number of flowering branches per plant was recorded by treatment with $200 \mathrm{mg} / \mathrm{L}$ hormone and the lowest number of days to flowering was related to $300 \mathrm{mg} / \mathrm{L}$ treatment. Also, the duration of the flowering period in $200 \mathrm{mg} / \mathrm{L}$ treatment wasat the maximum level.As a result,it was found that with increasing GA3 concentration the growth parameters of the plant increased.

To evaluate the effect of $0,100,200$ and $400 \mathrm{mg} / \mathrm{l}$ gibberellic acid on qualitative and quantitative characteristics of two varieties of Snapdragon, an experiment was carried out by Chehrazi et al. (2017). Seedlings, 50 days after seeding, were treated with different levels of gibberellic acid (leaf spraying) (in the 6 to 8 real leaves). The obtained results indicated that increasing the concentration of gibberellic acid meaningfully increased the studied traits. The maximum length and diameter of flowering branch, inflorescence length, and number of florets, number of leaves, durability of flowers and also the fresh weight of aerial parts were obtained from the interaction of 400 and $200 \mathrm{mg} / \mathrm{L}$ of gibberellic acid and yellow variety and then white variety. Among the different concentrations of gibberellic acid, the highest diameter of the florets, leaf area, chlorophyll, as well as dry weight of the aerial parts was related to $400 \mathrm{mg} / \mathrm{l}$ treatment and the lowest was related to the control group. Leaf area and dry weight of aerial parts in yellow variety were higher than the white variety.

In a study in line with the effect of regulating gibberellic acid on Polianthes tuberosaflowering and quality by Mortezaei Nejad and Etemadi (2010), concentrations of 100, 200, 250 and $300 \mathrm{mg} / \mathrm{L}$ of gibberellin hormone with control by soaking bulbs prior to planting and also soaking bulbs and foliar sprouting spraying was applied. The results showed that there was no significant difference between usingthe hormone in an immersed state before planting and hormone spray. In the treatment of 100 and $200 \mathrm{mg} / \mathrm{L}$, the seedlings were germinated earlier and then reproductive buds were observed in the concentrations of 250 , control and $300 \mathrm{mg} / \mathrm{L}$. The number of florets in the treatment of 250 and $300 \mathrm{mg} / \mathrm{L}$ was more than the others. The highest number ofthe harvested flower was in the treatment of $300 \mathrm{mg}$ and the lowest was observed in the control. Treatment of 250 and 300 $\mathrm{mg} /$ Lbring flowering time forward by 2 to 3 weeks compared with control.

\section{Salicylic acid}

Salicylic acid is widely known throughout the plant kingdom because,from the past, it has been found in more than 34 plant species. Salicylic acid is recognized in leaves and plant reproductive system and is found mostly in inflorescences of tropical plants and plants infected with necrosis pathogens (Arteca, 1950). 


\section{Using salicylic acid on the growth and flowering quality of plants in different investigations}

This plant growth regulator during application on plants affects a variety of physiological processes, such as stomatal closure, flowering induction, and other processes. The inner salicylic acid of the plant improves the flowering process in the plants. In addition, the external application of this plant growth regulator in the culture medium also results in the flowering of the Lemna. Also spraying this hormone leads to a significant increase in leaf area, length and diameter of flower buds, stalk length, and also increase the fresh and dry weight of the plant and improve the quality of rose cut flowers (Mansouri et al., 2015).

Investigating the effect of salicylic acid on growth and flowering of African violets was done by Martin et al. (2005) by means of $0,0.001,0.01$ and $0.1 \mu \mathrm{M}$ concentrations through spraying 18,25 and 32 days after transferring the plants to the pot. It was observed that at all concentrations were increasedby $16 \%$ in leaf volume compared to the control. Though in the $0.001 \mu \mathrm{M}$ treatment, this increase was higher than other treatments and it was equal to 19 percent. Also, a significant increase in the diameter of the peduncle was observed in all treatments as compared to control andin the $0.001 \mu \mathrm{M}$ treatment, this increase was higher than other treatments and it was equal to $27 \%$.

The number of flowers also increased with the usage of this hormone, so that at a $0.001 \mu \mathrm{M}$ of salicylic acid concentration, the number of flowers increased by $75 \%$ compared with the control. Also, the number of flowers in concentrations of 0.1 and $0.01 \mu \mathrm{M}$ was increased up to $25 \%$ and $37 \%$ compared with the control treatment. In each of these hormone concentrations, the flower induction occurred about 8 to 15 days earlier than the control. So, the best treatment for growth and flowering of this plant was $0.001 \mu \mathrm{M}$ of salicylic acid. From this experiment, it can be concluded that salicylates have a significant effect on parameters such as the number of flowers per plant and number of days until the flowering of African violets (Martin et al., 2005).

To investigate the effect of salicylic acid on flowering of Gloxinia, an experiment was designed by Martin et al. (2015) andduring this experiment, four treatments, different concentrations of salicylic acid (0, 0001, 0.01 and $0.1 \mu \mathrm{M})$ on 18th, 25th and 32nd days after flowering were sprayed on the potted plant and the researchers achieved fascinating results. They observed that in all the plants under treatment flower development occurred 24 days after the last hormone application stage, though in the control plants no flower was observed until 33 days after the hormone application. Using salicylic acid increased the number of flowers by $37 \%$ compared with the control treatment. Furthermore, using this hormone, induced earlier flowering and more flowers per plant than the control. This hormone also increased the flower size so that the concentration of $0.1 \mu \mathrm{M}$ produced the largest flower than the control.

\section{Experiment duration}

\section{Method}

This experiment initiated in the course of a 21-month period from November 2016 and it was ended in July of 2018.

\section{Place of experiment execution}

Thisplan was carried out in the Noshahr city located in Mazandaran province, with the northern latitude of $35^{\prime} 37^{\prime \prime}$ and eastern longitude of 50'42"and 2.9 meters above sea level.

\section{Experiment design}

In order to investigate the effect of hormonal treatment of gibberellic acid and salicylic acid, this study was done in the form of 5 experiments, as follows.

\section{Investigating the effect of the hormonal composition of GA3 and SA on growth and flowering of African violet seedlings}

This experiment was conducted as a factorial experiment in a completely randomized design with 3 levels of gibberellic acid: (1) concentration of $0 \mathrm{mg} / \mathrm{L}$ (control treatment), level,(2) concentration of $50 \mathrm{mg} / \mathrm{L}$ and (3) concentration of $100 \mathrm{mg} / \mathrm{L}$, and 3 levels of salicylic acid: (1)concentration of $0 \mu \mathrm{M}$ (control treatment), (2)concentration of $0.01 \mu \mathrm{M}$ and (3)concentration of $0.01 \mu \mathrm{M}$. This experiment was conducted on two Rapsody and Tong wensis varieties, which has 5 replicates for each hormone level. This experiment was performed in Peat moss culture medium: Perlite was done with equal ratio. Nutrition was done with solid fertilizer 20:20:20. Using each level of each hormone was done separately in two stages and 20 and 35 days after transferring the seedlings to the pot in the evening on the leaves and developing buds of the plant.

\section{Plant materials}

Seedlings resulted from tissue culture include three varieties Optimara, Rapsody and Tong wensis were used in the 6 to the 7-leaf stage with $0.7 \mathrm{~cm}$ diameter with suitable uniformity which was produced in the tissue culture laboratory of Noshahr, were used in the current research. 


\section{The way ofcontrolling environmental factors}

Due to the recording the ambient temperature of the laboratory, the maximum temperature was set to $25^{\circ} \mathrm{C}$ and at $18^{\circ} \mathrm{C}$, respectively at day and night. The relative humidity of the environment was set at 55-45\%.

\section{Measuring morphological traits}

The number of leaves of each treatment after the accomplishment of each experiment was counted. The total number of flowers appearing on the plant was observed and repeated note takingswas conducted during the plant growth period and until the end of the experiment. The total number of appeared buds on the plant during the experiment was counted. The number of branches of each treatment was counted after each trial period. The number of days to flowering per plant was carried out with repeated note takings during the plant growth period and until the end of the experiment. The durability of flowers per plant was recorded by repeated note takings during the plant flowering period from the time the flower was completely opened until maintaining the full beauty of the flower. The diameter of flowers was measured by means of calipers and the mean diameter was used for statistical analysis. The leaf area was measured by means of the Digimizer software. The plantroot was exposed to $70^{\circ} \mathrm{C}$ for 48 hours at the oven and their dry weight was measured. The number of flowers per inflorescence per plant was counted separately. The time period betweenobserving the first budand the last flower on the plant was measured. The distance between flowering periods from the end of each flowering period to the beginning of the next period was measured. The height of each plantfrom the surface of the potting soil was measured with a ruler. The length of each inflorescence was measured by a rulerin eachplant.

\section{Statistical Analysis}

Statistical analysis was performed with Minitab 16 software and the comparing the means was performed based on Tukey's test at 5\% probability level. Charts are plotted with Excel.

\section{Results and discussion}

Investigation the effect of hormonal treatment of gibberellic acid and salicylic acid and cultivar on growth and flowering of African violet seedlings

Based on table (1), the results of the analysis of variance and the data mean comparison showed that hormonal treatments and cultivar effect on most of the measured traits of African violet are meaningful. Hormonal treatments had a significant effect on traits such as number of leaves, number of buds, flower durability, days to flowering, leaf area, root dry weight, flowering period, flower number, the period between flowering, plant height and inflorescence length. Though, it had no significant effects on the traits such as a number of flowering branches and the number of flowers in inflorescences. The effect of cultivar on all traits except the number of flowering branches and the number of days until flowering was significant.

Based on Table 1, the results of the analysis of variance and comparison of data mean indicated that the interactions between hormonal and cultivar treatments were significant on traits such as leaf number, flower number, leaf area, flowering period, plant height and inflorescence length,but they had no significant effect on other traits.

Table 1: Analysis of variance (mean square) effect of hormonal and cultivar treatments on morphological traits of African violets

\begin{tabular}{|c|c|c|c|c|c|c|c|c|c|c|c|c|c|c|c|}
\hline $\begin{array}{c}\text { Sources of } \\
\text { changes }\end{array}$ & df & $\begin{array}{l}\text { Number } \\
\text { of leaves }\end{array}$ & $\begin{array}{l}\text { Number } \\
\text { of flowers }\end{array}$ & $\begin{array}{l}\text { Number } \\
\text { of buds }\end{array}$ & $\begin{array}{c}\text { Number } \\
\text { of } \\
\text { flowering } \\
\text { branches }\end{array}$ & $\begin{array}{l}\text { Number } \\
\text { of days to } \\
\text { flowering }\end{array}$ & $\begin{array}{c}\text { Flower } \\
\text { life }\end{array}$ & $\begin{array}{c}\text { Flower } \\
\text { diameter }\end{array}$ & $\begin{array}{l}\text { Leaf } \\
\text { area }\end{array}$ & $\begin{array}{c}\text { Root } \\
\text { dry } \\
\text { weight }\end{array}$ & $\begin{array}{l}\text { Number } \\
\text { of } \\
\text { flowers } \\
\text { in } \\
\text { infloresc } \\
\text { ences }\end{array}$ & $\begin{array}{c}\text { Flowering } \\
\text { period }\end{array}$ & $\begin{array}{l}\text { The } \\
\text { distance } \\
\text { between } \\
\text { flowering } \\
\text { periods }\end{array}$ & $\begin{array}{l}\text { Plant } \\
\text { height }\end{array}$ & $\begin{array}{c}\text { Infloresc } \\
\text { ence } \\
\text { length }\end{array}$ \\
\hline $\begin{array}{l}\text { Hormonal } \\
\text { treatment }\end{array}$ & 4 & $116.9^{* *}$ & $157.9^{* \star}$ & $149.5^{* \star}$ & $1516 \mathrm{~ns}$ & $368.9^{* \star}$ & $11.3^{* \pi}$ & $0.7^{* *}$ & $4.0^{* \pi}$ & $0.9^{* *}$ & $1.0 \mathrm{~ns}$ & $48.2^{* *}$ & $329.1^{* \pi}$ & $26.4^{* *}$ & $31.4^{* *}$ \\
\hline Cultivator & 1 & $442.1^{* *}$ & $1169.6^{* *}$ & $708.1^{* *}$ & $470 \mathrm{~ns}$ & $91.2 \mathrm{~ns}$ & $57.2^{* *}$ & $8.2^{* *}$ & $479.6^{* *}$ & $0.3^{* *}$ & $24.0^{* *}$ & $184.1^{* *}$ & $1476.4^{* *}$ & $226.1^{* *}$ & $344.0^{* *}$ \\
\hline $\begin{array}{l}\text { Interactio } \\
\mathrm{n} \text { between } \\
\text { hormonal } \\
\text { and } \\
\text { cultivar } \\
\text { treatment }\end{array}$ & 4 & $13.3^{* *}$ & $55.8^{*}$ & $13.7 \mathrm{~ns}$ & $1765 \mathrm{~ns}$ & $24.6 \mathrm{~ns}$ & $1.0 \mathrm{~ns}$ & $0.06 \mathrm{~ns}$ & $0.6^{*}$ & $0.09 \mathrm{~ns}$ & $0.5 \mathrm{~ns}$ & $38.32^{* *}$ & $7.5 \mathrm{~ns}$ & $7.5^{\text {** }}$ & $3.1^{* *}$ \\
\hline Error & 48 & 1.6 & 7.5 & 6.8 & 39 & 40.56 & 1.0 & 0.1 & 0.2 & 0.4 & 0.4 & 2.8 & 23.4 & 0.2 & 0.1 \\
\hline
\end{tabular}

$\mathrm{ns}, *$, and $* *$ - respectively, were insignificant, significant at the probability level of 5 and $1 \%$ based on the Tukey's test 
Table 2:The results of the comparison of the effect of hormonal treatments on the morphological traits of African violets

\begin{tabular}{|c|c|c|c|c|c|c|c|c|c|c|c|c|c|}
\hline $\begin{array}{l}\text { Treatme } \\
\text { nt type }\end{array}$ & $\begin{array}{c}\text { Density } \\
\text { (milligram) } \\
\text { (Micromola } \\
\text { r) }\end{array}$ & $\begin{array}{l}\text { Number } \\
\text { of leaves }\end{array}$ & $\begin{array}{l}\text { Number of } \\
\text { flowers }\end{array}$ & $\begin{array}{l}\text { Number } \\
\text { of buds }\end{array}$ & $\begin{array}{l}\text { Number } \\
\text { of days to } \\
\text { flowering }\end{array}$ & $\begin{array}{c}\text { Flower } \\
\text { life }\end{array}$ & $\begin{array}{c}\text { Flower } \\
\text { diameter } \\
\text { (centimete } \\
\text { (rs }\end{array}$ & $\begin{array}{l}\text { Leaf area } \\
(\mathrm{cm})\end{array}$ & $\begin{array}{l}\text { Root dry } \\
\text { weight (g) }\end{array}$ & $\begin{array}{l}\text { Flowering } \\
\text { period }\end{array}$ & $\begin{array}{c}\text { The interval } \\
\text { between } \\
\text { flowering } \\
\text { periods }\end{array}$ & $\begin{array}{l}\text { Plant } \\
\text { height } \\
(\mathrm{cm})\end{array}$ & $\begin{array}{l}\text { Inflorescen } \\
\text { ce length } \\
(\mathrm{cm})\end{array}$ \\
\hline Control & 0 & cl5.3 & $15.8 \mathrm{c}$ & $17.8 \mathrm{c}$ & $52.3 \mathrm{a}$ & $6.1 \mathrm{~b}$ & $1.7 \mathrm{~b}$ & $6.7 \mathrm{c}$ & $2.7 \mathrm{~b}$ & $13.9 \mathrm{~d}$ & 33.1a & $8.2 \mathrm{c}$ & $7.8 \mathrm{~d}$ \\
\hline $\mathrm{GA} 3$ & 50 & $20.8 \mathrm{~b}$ & $24.0 \mathrm{a}$ & $24.5 \mathrm{ab}$ & $42.8 \mathrm{~b}$ & $7.6 \mathrm{a}$ & $1.8 \mathrm{ab}$ & 7.9ab & $3.3 \mathrm{a}$ & $14.7 \mathrm{~cd}$ & $26.0 \mathrm{~b}$ & $10.6 \mathrm{~b}$ & $10.8 \mathrm{~b}$ \\
\hline $\mathrm{GA} 3$ & 100 & a22.9 & $23.2 \mathrm{ab}$ & $256.9 \mathrm{a}$ & $40.3 \mathrm{~b}$ & $7.7 \mathrm{a}$ & $1.9 \mathrm{ab}$ & $8.0 \mathrm{a}$ & $3.2 \mathrm{a}$ & $15.9 \mathrm{bc}$ & $21.2 \mathrm{~b}$ & $11.4 a$ & $11.7 \mathrm{a}$ \\
\hline SA & 0.01 & b19.3 & $20.3 \mathrm{~b}$ & $22.3 \mathrm{~b}$ & 44.lb & $5.5 \mathrm{~b}$ & $2.2 \mathrm{a}$ & $7.3 \mathrm{~b}$ & 3.la & $17.6 \mathrm{ab}$ & 25.1b & $10.5 b$ & $9.6 \mathrm{c}$ \\
\hline SA & 0.1 & b 20.5 & $22.0 \mathrm{ab}$ & $24.3 \mathrm{ab}$ & $40.3 \mathrm{~b}$ & $5.8 \mathrm{~b}$ & $2.2 \mathrm{a}$ & 7.7ab & $3.3 \mathrm{a}$ & $18.8 \mathrm{a}$ & $21.9 \mathrm{~b}$ & $11.4 a$ & $10.3 \mathrm{~b}$ \\
\hline
\end{tabular}

The means in each column that according to the Tukey's test have at least one common alphabetdo not have a significant difference at the $1 \%$ probability level.

Table 3: Results of comparison of the effect of cultivar on morphological traits of African violets under hormonal treatments

\begin{tabular}{|c|c|c|c|c|c|c|c|c|c|c|c|c|}
\hline & \multicolumn{12}{|c|}{ Traits } \\
\hline Cultivar & $\begin{array}{l}\text { Number } \\
\text { of leaves }\end{array}$ & $\begin{array}{c}\text { Number } \\
\text { of } \\
\text { flowers }\end{array}$ & $\begin{array}{l}\text { Number } \\
\text { of buds }\end{array}$ & $\begin{array}{l}\text { Number of } \\
\text { flowers in } \\
\text { inflorescences }\end{array}$ & $\begin{array}{c}\text { Flower life } \\
\text { (day) }\end{array}$ & $\begin{array}{c}\text { Flower } \\
\text { diameter } \\
\text { (cm) }\end{array}$ & $\begin{array}{l}\text { Leaf } \\
\text { area } \\
(\mathrm{cm} 2)\end{array}$ & $\begin{array}{l}\text { Root dry } \\
\text { weight (g) }\end{array}$ & $\begin{array}{c}\text { Flowering } \\
\text { period } \\
\text { (day) }\end{array}$ & $\begin{array}{l}\text { The interval } \\
\text { between } \\
\text { flowering } \\
\text { periods }\end{array}$ & $\begin{array}{c}\text { Plant } \\
\text { height } \\
\text { (centime } \\
\text { (ters }\end{array}$ & $\begin{array}{c}\text { Inflorescence } \\
\text { length } \\
\text { (centimeters) }\end{array}$ \\
\hline Rhapsody & $16.9 \mathrm{~b}$ & $25.7 \mathrm{a}$ & $26.6 \mathrm{a}$ & 4.1a & $7.6 \mathrm{a}$ & $2.3 \mathrm{a}$ & 10.5 & $3.0 \mathrm{~b}$ & $18.0 \mathrm{a}$ & $20.2 \mathrm{~b}$ & $8.4 \mathrm{~b}$ & $7.5 \mathrm{~b}$ \\
\hline Tong wensis & $22 a$ & $16.4 \mathrm{~b}$ & $19.3 \mathrm{~b}$ & $2.8 \mathrm{~b}$ & $5.5 \mathrm{~b}$ & $1.6 \mathrm{~b}$ & $4.5 b$ & $3.2 \mathrm{a}$ & $14.3 \mathrm{~b}$ & $30.7 \mathrm{a}$ & $12.5 \mathrm{a}$ & $12.6 \mathrm{a}$ \\
\hline
\end{tabular}

The means in each column that according to the Tukey's test have at least one common alphabet do not have a significant difference at the $1 \%$ probability level.

\section{Number of leaves}

The results of the analysis of variance indicated that the simple effect of hormonal treatments was significant at $1 \%$ probability level. The simple effect of cultivar and interaction between cultivars and hormonal treatments were also significant at the probability level of $1 \%$ (Table 7-4). The results of data mean comparison also revealed that the highest leaf number was observed in the treatment of $100 \mathrm{mg}$ gibberellic acid and in Tong wensis cultivar with mean of 27 leaves, which had a significant difference with other hormonal treatments in both cultivars. The lowest number of treatments was observed in control and Rhapsody cultivar with an average of 13.8 leaves, which had a significant difference with all hormonal treatments (Fig. 1).

Gibberellin increases the elasticity of the cell wall and, by concentrating Cell sap, through starch-to-sugar hydrolysis, decreases the water potential of the plant cell, and leads to water entry and cell elongation. Gibberellin increases the growth of plants and internode distance by increasing cell division and cell growth and increasing cell size. The stem height and the leaves number in the plants also increase for this reason. These results are consistent with the results of Ismaili's (2013) research. 


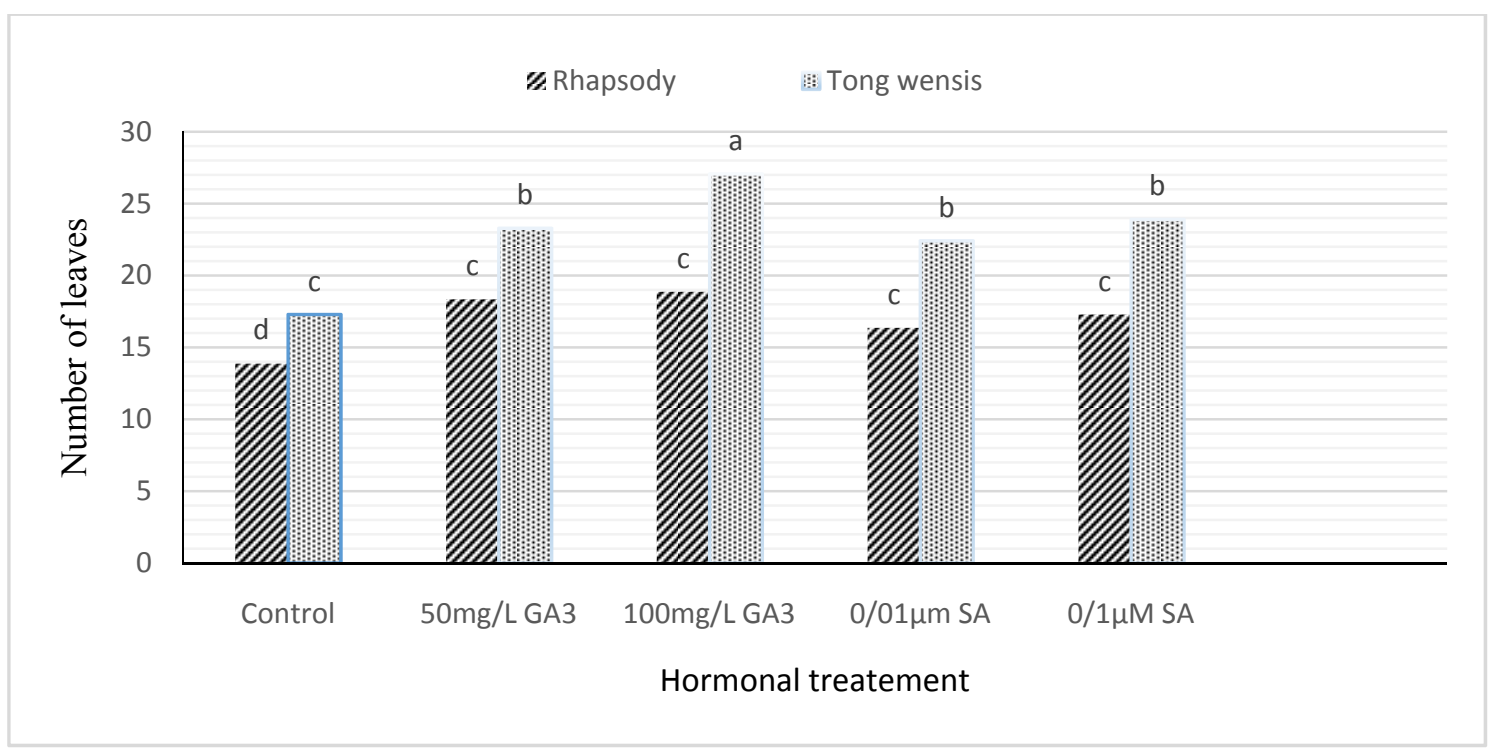

Figure 1: Interaction between hormonal treatments and cultivars on the average number of African violet leaves

\section{Number of flowers}

The results of the analysis of variance showed that the simple effect of hormonal treatments was significant at $5 \%$ probability level. The simple effect of cultivar was significant at $1 \%$ probability level. The effects of hormonal and cultivar interaction were significant at 5\% probability level (Table 1). The results of the mean comparison of data also disclosed that the highest number of flowers was observed in treatment with $50 \mathrm{mg}$ gibberellic acid and in Rhapsody cultivar with an average of $29.5 \%$ of flowers that did not have a significant difference with $100 \mathrm{mg}$ of this hormone treatment and salicylic acid treatments in Rhapsody cultivar. The lowest number of flowers was observed in control treatment and in Tong wensis cultivar with a mean of 13.1 of flowers, which had no significant difference with other treatments of thiscultivar, except for $50 \mathrm{mg} / \mathrm{L}$ in treatment of gibberellic acid (Fig.2).

By means of increasing the concentration of gibberellin in the plant, the number of flowers increases, but this hormone at high concentrations produces the most abnormal flower. These results are consistent with the results of Ismaili's et al. (2013) research. Salicylic acid is effective as an endogenous regulator for flowering, and by increasing protein synthesis and the appearance of isozyme bands, it induces and increases the number of flower buds. These results were consistent with the results of Martin's et al. (2015) research on African violets.

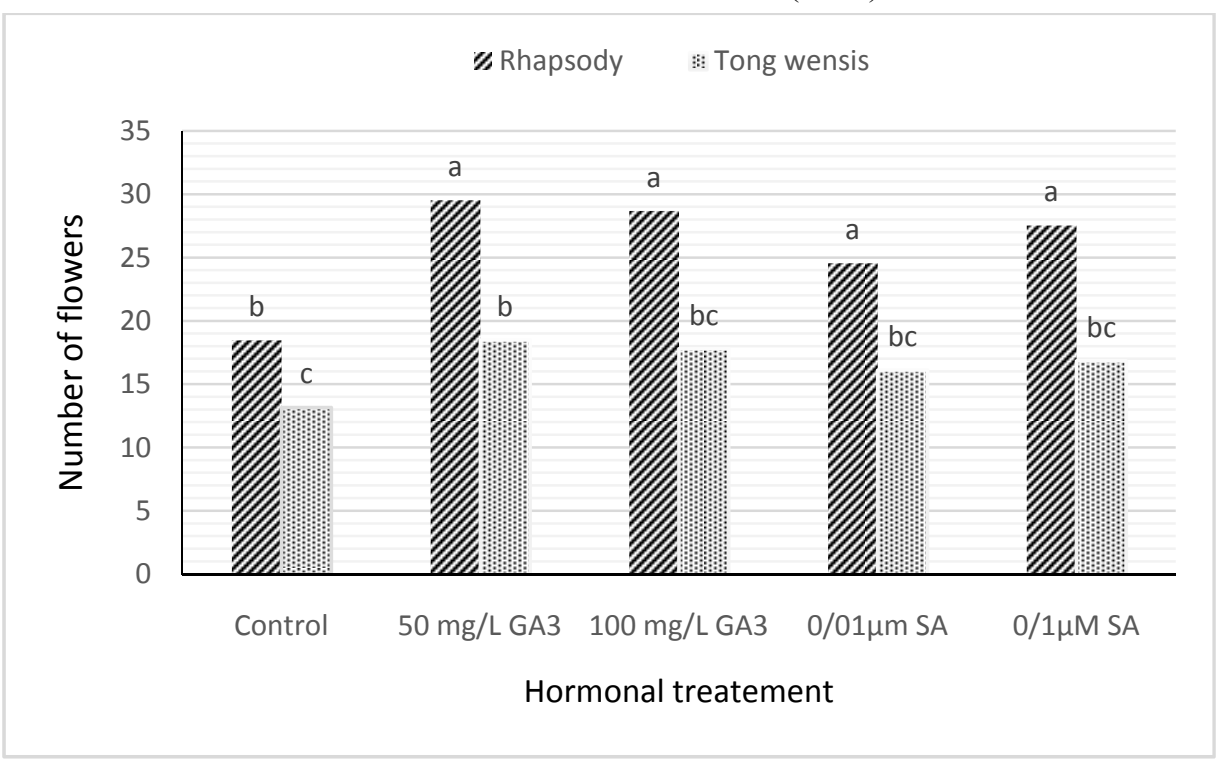

Figure 2: Interaction between hormonal treatments and cultivars on the average number of African violet flowers 


\section{Number of buds}

The results of the analysis of variance indicated that the simple effect of hormonal treatments was significant at $1 \%$ probability level. The simple effect of cultivar was significant at $1 \%$ level. However, the interaction between cultivar and Hormonal treatment was not significant (Table 1). The results of the comparison of the means of the data in the study of the effect of simple hormonal treatments showed that the highest number of buds was observed for treatments of $100 \mathrm{mg}$ gibberellic acid with a mean of 25.9 of budsandit did not havesignificant difference with treatments of $100 \mathrm{mg}$ gibberellic acid and $0.1 \mu \mathrm{M}$ salicylic acid but it was significantly different with other treatments. The lowest number of buds was observed in the control treatment with an average of 17.8 buds, which had a significant difference with other treatments (Table 2).

The results of the comparison of the mean of data in line with investigating the simple effect of cultivar revealed that the highest number of buds was observed in the Rhapsody cultivar with a mean of 26.6 buds, which had a significant difference with other cultivars. The lowest number of buds was observed in the Tong wensis cultivar with a mean of 19.3 buds, which had a significant difference with other cultivars (Table 3).

\section{Number of flowering branches}

The results of the analysis of variance showed that simple effect of hormonal treatments and simple effect of cultivar, and interaction between cultivars and hormonal treatments were not significant on a number of flowering branches (Table 1).

Gibberellinaffectsthe first flower of the plant and increases the reproductive growth and number of flowering branches and then increases the number of buds. These results were consistent with the results of Mortazai Nejad and Etemadi (2009) on the Polianthes tuberosa. It seems that Salicylic acid thorough increasingcell division and improving the photosynthetic condition increase growth and the number of flowers. These results are consistent with the results of Mansuri et al. (2015).

\section{Number of days until flowering}

The results of the variance analysis indicated that the simple effect of hormonal treatments was significant at $1 \%$ probability level. The simple effect of cultivar and the interaction between cultivars and hormonal treatments were not significant at the probability level of $1 \%$ and $5 \%$ (Table 7-4). The results of the comparison of data mean also disclosed that the highest number of days until flowering was observed in control treatment with a mean of 52.3 days, which had a significant difference with other treatments. The lowest number of days until flowering was observed in $100 \mathrm{mg}$ gibberellic acid treatment with an average of 40.3 days, which did not have a significant difference with other hormonal treatments (Table 2).

Studies on the effect of GA3 on ornamental plants revealed that gibberellin quickens flowering and increases plant height. As the concentration of gibberellin increases, acceleration at the flowering onset also increases. These results are consistent with the results of Ismaili's et al. (2013) research on zinnia.

\section{Flower durability}

The results of the analysis of variance exhibited that simple effect of hormonal treatments was significant at $1 \%$ probability level. The simple effect of cultivar was significant at $1 \%$ level of probability, but the interaction between cultivars and hormonal treatments was not significant (Table 7-4). The results of the comparison of the data mean in line with investigating the effect of simple hormonal treatments revealed that the highest flower durability was observed in the treatment of $100 \mathrm{mg}$ gibberellic acid with a mean of 7.7 days and then $50 \mathrm{mg}$ of gibberellic acid, which had a significant difference with other treatments. The lowest flower life was observed in $0.01 \mu \mathrm{M}$ salicylic acid treatment with a mean of 5.5 days, which did not havea significant difference with other salicylic acid and control treatments (Table 2).

The results of the comparison of the data mean in line with investigating the simple effect of cultivar revealed that the highest flower durability was observed in Rhapsody cultivar with a mean of 7.6 days, which had a significant difference with another cultivar. The lowest flower durability was observed in Tong wensis cultivar with an average of 5.5 days, which had a significant difference with another cultivar (Table 3 ).

Gibberellic acid, by acidifying the cell sap, postpones the aging process, because the cell sap alkalinization leads to cell membrane collapse, protein decomposition, and accumulation of ammonium in the margin of petals that is an important factor in accelerating aging. Also, gibberellic acid can extend the flower durability by delaying the respiratory peak in the plant. Gibberellic acid decreases the chlorophyll decomposition and elimination and nitrogen during the aging process that may be due to the structural role of gibberellic acid in the chloroplast membrane and ultimately leads to the stimulation of photosynthesis. Green leaves can be a reason for increasing the durability of flowers. These results are consistent with the results of Ismaili's et al. (2013) research on zinnia. 


\section{Flower diameter}

The results of the analysis of variance disclosed that the simple effect of hormonal treatments was significant at $1 \%$ probability level. The simple effect of cultivar was significant at $1 \%$ level. Though, the interaction between cultivars and hormonal treatments was not significant (Table 7-4). The results of the comparison of the data mean in line with investigating the effect of hormonal treatments indicated that the highest flower diameter was observed in salicylic acid treatments with an average of $2.2 \mathrm{~cm}$ that was not significantly different with gibberellic acid treatments. The lowest flower diameter was also observed in control treatment with a mean of $1.7 \mathrm{~cm}$ that was not significantly different with gibberellic acid treatments but it had a significant difference with other treatments (Table 2).

The results of the comparison of the data mean in line with investigatingthe simple effect of cultivar indicated that the highest flower diameter was observed in Rhapsody cultivar with an average of $2.3 \mathrm{~cm}$ that had a significant difference with other cultivars. The lowest flower diameter was seen in Tong wensis cultivars with a mean of $1.6 \mathrm{~cm}$ that had a significant difference with other cultivars (Table 3).

Gibberellic acid stimulates cell division and lengthens cell. In this way, this hormone may increase the diameter of the flower. These results are consistent with Ismaili's (2013) researchresults on zinnia. Due to its role in protein synthesis and increased cell division, Salicylic acid also has increased the flower's diameter in the plant. These results are consistent with the results of Jabarzadeh's (2006) research on the Saintpaulia and Mansouri's et al. (2014) research on the Gerbera flower. The role of salicylic acid in increasing the diameter of the flower can be due to protein synthesis and increased cell division. These results are consistent with the results of Jabarzadeh's et al. (2006) research on African violets.

\section{Leaf area}

The results of the analysis of variance indicated that the simple effect of hormonal treatments was significant at $1 \%$ probability level. The simple effect of cultivar was also significant at $1 \%$ level. The interaction between cultivars and hormonal treatments was significant at 5\% probability level (Table 1). The results of the comparison of the data mean also revealed that the highest leaf area was observed for treatment of $100 \mathrm{mg}$ gibberellic acid and in Rhapsody cultivar with an average of $11.3 \mathrm{~cm}^{2}$ that had significant difference with $50 \mathrm{mg}$ gibberellic acid and $0.1 \mu \mathrm{M}$ salicylic acid treatments in the Rhapsody cultivar but it had no significant difference with other treatments. The lowest leaf area was observed in control treatment and in Tong wensis cultivar with an average of $4.0 \mathrm{~cm}^{2}$ that did not havea significant difference with all treatments of this cultivar, but it had a significant difference with other treatments of Rhapsody (Fig. 3).

Gibberellic acid stimulates cell division and elongates cell. In this way, this hormone may increase the leaf area. These results are consistent with the results of Ismaili's et al. (2013) research on zinnia. Salicylic acid, like gibberellic acid, by increasing cell division in the plant, increases the growth and also the leaf area of the plant. These results are consistent with the results of Jabarzadeh's et al. (2006) research on African violet.

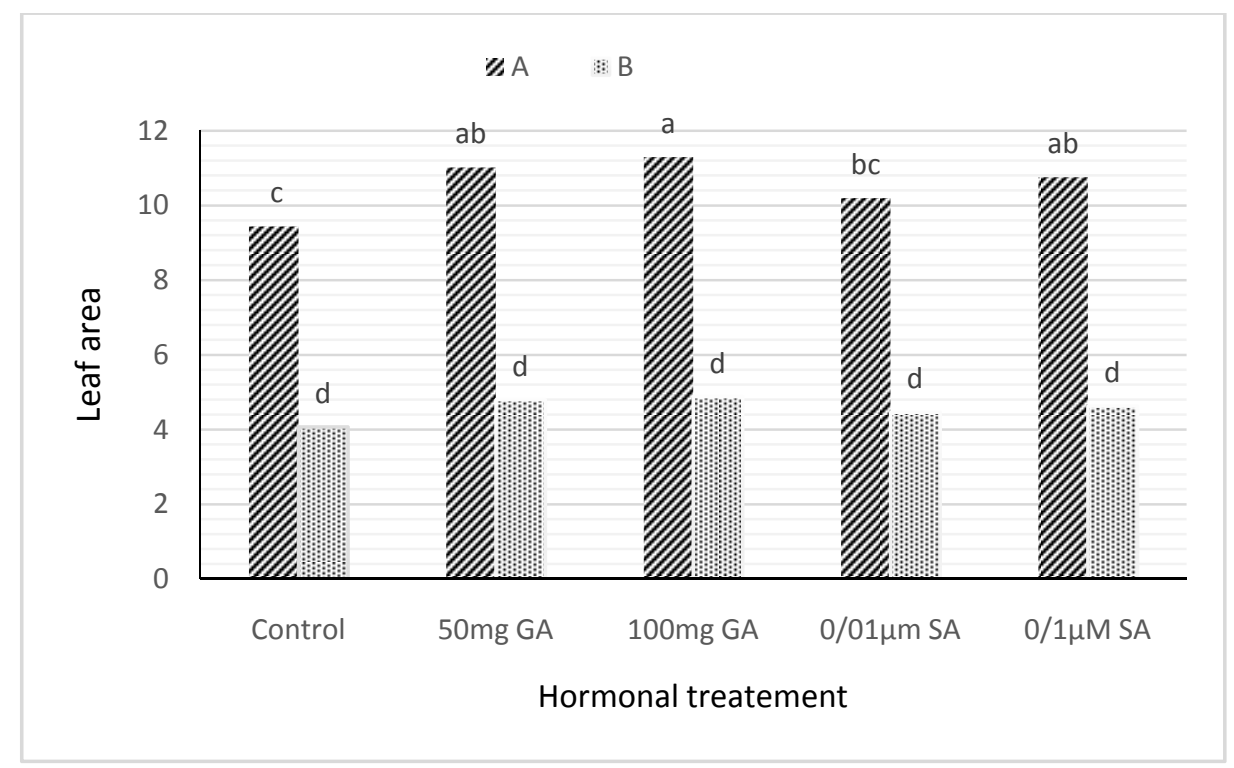

Figure 3: Interaction between hormonal and cultivar treatments on the average level of African violet leaves 


\section{Root dry weight}

The results of the analysis of variance indicated that the simple effect of hormonal treatments was significant at $1 \%$ probability level. The simple effect of cultivar was significant at $1 \%$ level, but the interaction between cultivars and hormone treatment was not significant (Table 1). The results of the comparison of the data mean line with investigating the effect of simple hormonal treatments disclosed that the highest root dry weight was observed in $0.1 \mu \mathrm{M}$ salicylic acid treatment with a mean of $3.3 \mathrm{~g}$ that had no significant difference with all hormonal treatments. The lowest root dry weight was observed in control treatment with an average of $2.7 \mathrm{~g}$ that had a significant difference with all hormonal treatments (Table 2).

The results of the comparison of data mean in line with investigating the simple effect of cultivar showed that the highest root dry weight was observed in Tong wensis cultivarwith an average of $3.2 \mathrm{~g}$ that had a significant difference with another cultivar. The lowest root dry weight was observed in Rhapsody cultivar with an average of $3.0 \mathrm{~g}$ that had a significant difference with other cultivars (Table 3 ).

Gibberellin is known as a plant growth stimulator hormone, and it's stimulant effect increases root growth and development. These results are consistent with the results of Arvin (2013) on Satureja.

The positive effect of salicylic on growth parameters is the result of increased carbon dioxide absorption and an increase in the relative chlorophyll concentration and photosynthesis ratio. These results are consistent with the results of Mansouri's et al. (2015) research.

\section{Number of flowers in inflorescences}

The results of the analysis of variance showed that the simple effect of hormonal treatments was not significant. The simple effect of cultivar was significant at $1 \%$ probability level. Though, the interaction between cultivars and hormonal treatments was not significant (Table 7-4). The results of the data mean comparison also indicated that the highest number of flowers in inflorescence was observed in Rhapsody cultivar with an average of 4.1 flowers that had a significant difference with other cultivars. The lowest number of flowers in inflorescence was observed in Tong wensis cultivars with an average of 2.8 flowers that had a significant difference with other cultivars (Table 3).

\section{Flowering period}

The results of the analysis of variance revealed that the simple effect of hormonal treatments was significant at $1 \%$ probability level. The simple effects of cultivars and the interaction between cultivars and hormonal treatments were also significant at $1 \%$ probability level (Table $7-4$ ). The results of the data mean comparison also indicated that the highest flowering period was observed in $0.1 \mu \mathrm{M}$ salicylic acid and in the Rhapsody cultivar with a mean of 23.1 days that did not havea significant difference with $0.01 \mu \mathrm{M}$ salicylic acid in Rhapsody but it had a significant difference with other treatments. The lowest flowering period was observed in the control treatment and in Tong wensis cultivar with a mean of 12.6 days. The lowest flowering period did not have a significant difference with other treatments except for treatment of $50 \mathrm{mg}$ gibberellic acid in Rhapsody and both salicylic acid concentrations in Tong wensis cultivar. But it had a significant difference with other treatments (Fig. 4).

It seems that the positive effects of salicylic acid on growthare the result of increased $\mathrm{CO}_{2}$ absorption, relative chlorophyll, and the photosynthesis rate. These results are consistent with the results of Martin's et al. (2015) research on African violets. 


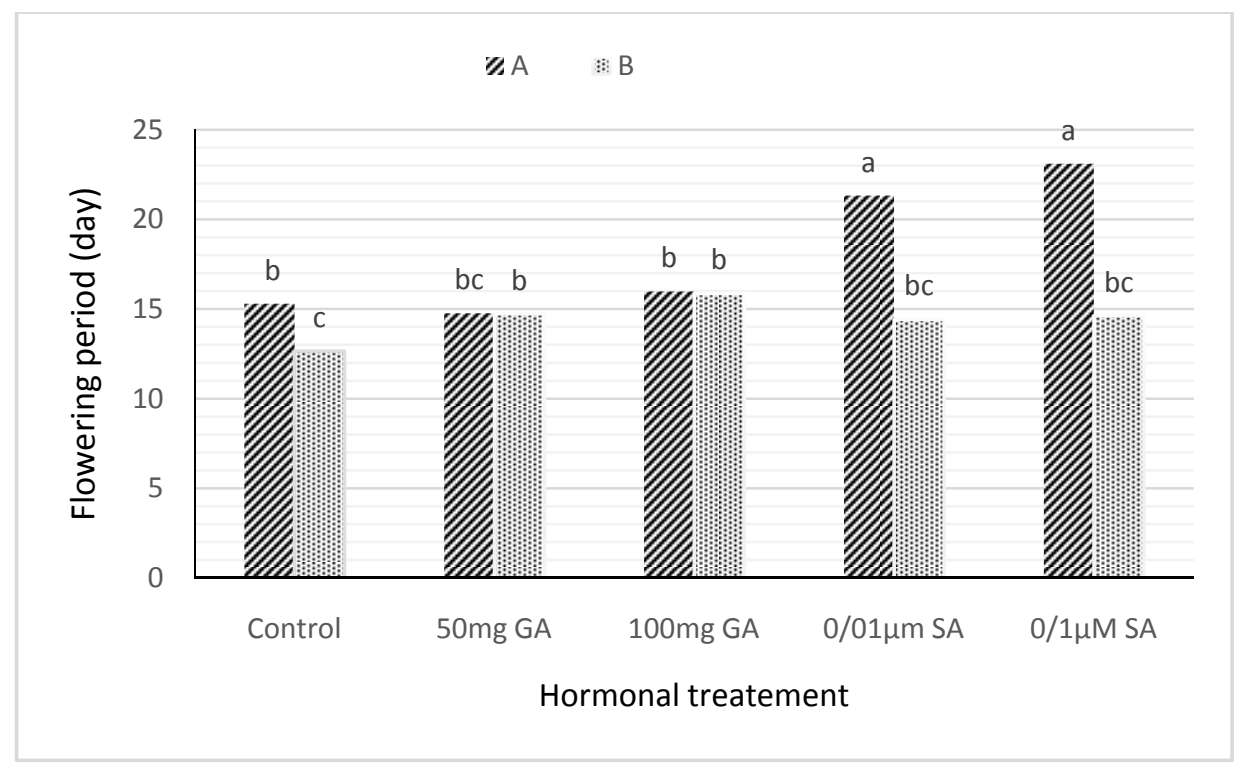

Figure 4: Interaction between hormonal and cultivar treatments on the mean flowering time of African violets

\subsubsection{The distance between flowering periods}

The results of the analysis of variance revealed that the simple effect of hormonal treatments was significant at $1 \%$ probability level. The simple effect of cultivar was significant at $1 \%$ probability level, but the interaction between cultivars and hormonal treatments was not significant (Table 1). The results of the comparison of data mean in line with investigating the effect of hormonal treatments revealed that the maximum distance between flowering periods was observed in control treatments with an average of 33.1 days, which had a significant difference with other treatments. The lowest difference between flowering periods was observed in $100 \mathrm{mg}$ gibberellic acid treatment with a mean of 21.2 days, which had no significant difference with other hormonal treatments but had a significant difference with controltreatment (Table 2).

The results of the comparison of the data mean in line with investigating the simple effect of cultivar indicated that the maximum distance between flowering periods was in Tong wensis cultivar with a mean of 30.7 days that had a significant difference with other cultivars. The least period was observed between flowering periods in Rhapsody cultivar with a mean of 20.2 daysthat had a significant difference with other cultivars (Table 3).

\section{Plant height}

The results of the analysis of variance revealed that the simple effect of hormonal treatments was significant at $1 \%$ probability level. The simple effect of cultivar was significant at $1 \%$ probability level. The interaction between the cultivar and the hormonal treatment was also significant at $1 \%$ probability level (Table 1 ). The results of the data mean comparison also disclosed that the highest plant height was observed in treatment with $100 \mathrm{mg}$ gibberellic acid and in Tong wensis cultivar with an average of $14.4 \mathrm{~cm}$ that did not havea significant difference with $50 \mathrm{mg}$ gibberellic acid in this cultivar, but it had asignificant difference with other treatments. The lowest plant height was observed in Tong wensis cultivar with a mean of 6.8 that did not have a significant differencewith $50 \mathrm{mg}$ treatment of this hormone, but it was significantly different with other treatments (Fig. 5).

Gibberellin increases plant growth and internode distance by increasing cell division and cell growth, increasing cell size, stem height and leaf number. These results are consistent with the Ismaili's (2013) research results on zinnia.

By increasing the concentration of salicylic acid, the number of photosynthesis pigments, especially chlorophyll, and cell division are increased in the plant and increased plant height. 


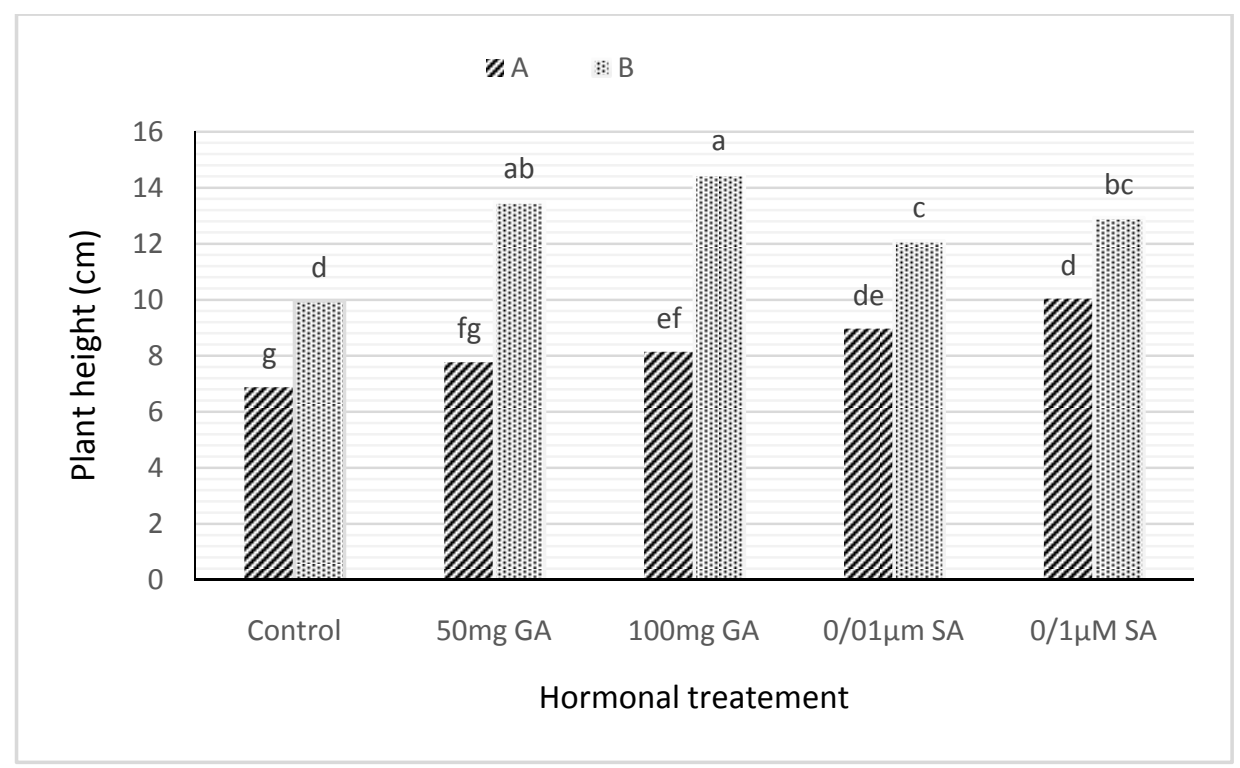

Figure 5: Interaction between hormonal and cultivar treatments on average height of African violet plant

\section{Inflorescence length}

The results of the analysis of variance disclosed that the simple effect of hormonal treatments was significant at $1 \%$ probability level. The simple effect of cultivar and the interaction between cultivar and treatment was significant at $1 \%$ probability level (Table 7-4). The results of the comparison of the data mean also indicated that the highest amount of inflorescence was observed in the treatment of $100 \mathrm{mg}$ gibberellic acid and in Tong wensis cultivar with $14.8 \mathrm{~cm}$ centimeters that had a significant difference with other treatments. Control treatment showed a significant difference in Rhapsody cultivars with a mean of $5.9 \mathrm{~cm}$ with the lowest inflorescence length had a significant difference with all hormonal treatments (Fig. 6).

The longitudinal growth of the airborne organs in plants stimulated by gibberellin, is the result of increased cell division, elongation of cells or both, by increasing the activity of the xyloglucan endotransglycosylase activity increase cell wall dilatation, and its result is cell wall softening and allows the cell to be pulled and lengthened under the influence of Turgor pressure, on the other hand, it increases due to the activity of the invertase enzyme in the plant, which increases the hexoses required for the growth of the cell wall, so causes the longitudinal growth of the aerial section. These results were consistent with the results of Arvin (2013) on Satureja.

By increasing cell division in the terminal meristem region and elongation of the cell, salicylic acid increases growth. This result is consistent with the results of Jabarzadeh's et al. (2006) research on African violets.

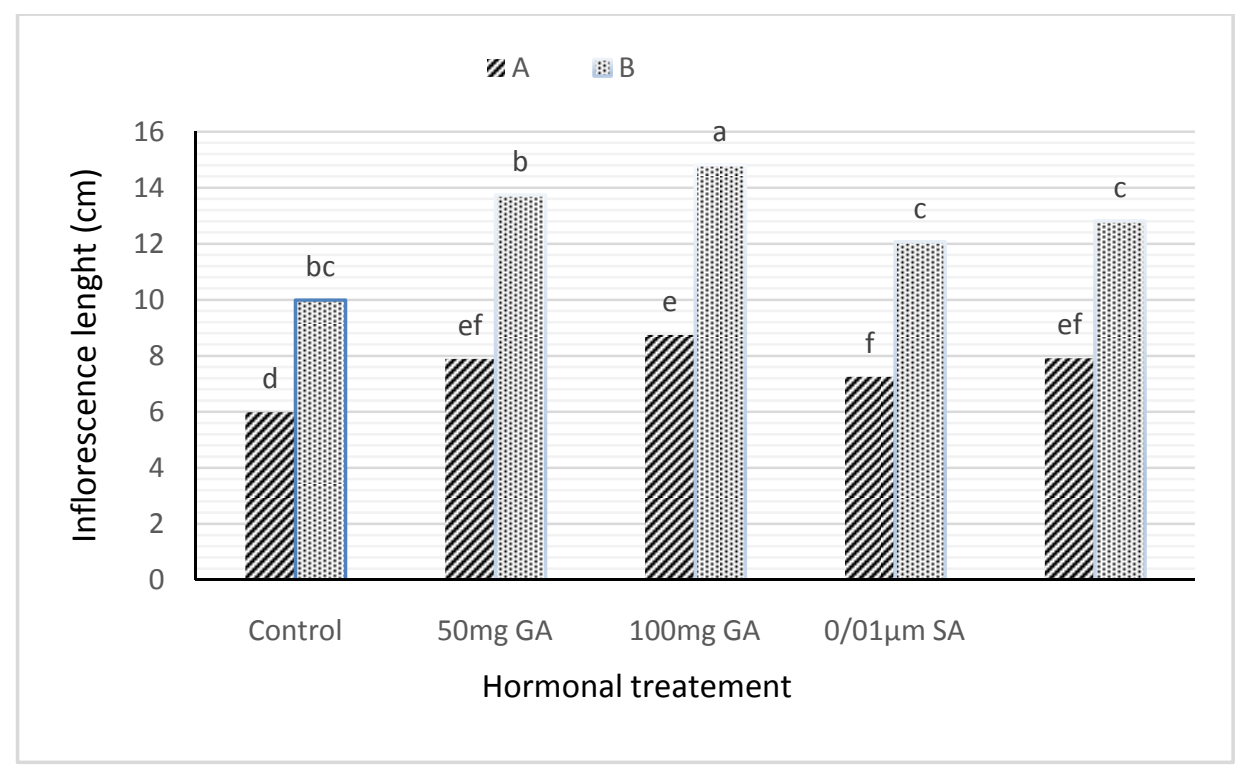

Figure 6: Interaction between hormonal treatments and cultivars on the average length of African violet inflorescences 
Generally, by increasing GA3 concentration, the number of days from foliar application until flowering peak decreases so that the minimum number of days to flowering was in $100 \mathrm{mg} / \mathrm{L}$, but the average number of flowers decreased in this treatment. Consequently, applying Gibberellin hormonal treatment on this plant accelerated flower development and simultaneously flowers opening, which was consistent with the results of Nowruzi's (2012) research. It was also observed that with increasing gibberellin concentration, the length of the peduncle increased in African violets.

In addition to these traits, salicylic acid improves other important parameters in flowering, such as flower number, flower diameter, flower life (durability), flowering period, number of days until flowering and other flowering parameters. So, salicylic acid has a better effect on the appearance or flowering phenotype African violet, and in addition to increasing the amount of growth and flowering, it also improves the appearance of this plant. These results were consistent with the results of Martin's (2005) study in line with the effect of salicylic acid on African violets.

\section{Conclusion}

In the experiment of the effect of gibberellin acid on the plant,by increasing the concentration of this hormone, the petiole length was increased and in the concentration of $100 \mathrm{mg}$ of this hormone, the maximum length of the petiole was observedthat was not acceptable in terms of aesthetics. The suitable morphology for growth and flowering in this plant was observed in the treatment of $50 \mathrm{mg}$ of this hormone that is suggested for improving the phenotypic condition of this plant in compact and compact leafy cultivars. In terms of flowering, the increase in the concentration of this hormone increased significantly in flowering, but the highest concentration of this hormone had a negative effect on the quality and shelf life of flowers. According to these results, the best flowering and growth conditions in the African violet plant occurs in the appropriate concentration of gibberellin hormone.

In the discussion of using SA hormone in African violet, it was observed that by increasing the concentration of this hormone in the plant, the measured traits increased; consequently, to improve the flowering in this plant 0.1 $\mu$ Mtreatment of this hormone has the highest flower and the most suitable quality and the flower durability was also suitable. It was also observed that increasing the concentration of salicylic acid hormone significantly reduced the number of days until flowering.

\section{References}

[1] Arvin, P. (2013). Effect of gibberellin on some morphological traits, photosynthetic pigments content and proline in savory (Satureja hortensis L.) under salinity stress conditions, Journal of Crop Production Research, 7(2).

[2] Ismaili, S., Rohi, A., Shiran, B., Mohammad Khani, A. (2013). Investigating the effects of calcium chloride, gibberellin and benzil adenine hormones on quantitative, qualitative characteristics and (Zinnia elegans J.) Zinnia life span.Journal of Horticultural Science (Agricultural Sciences and Technology), 27(4),pp. 35-41.

[3] Chehrazi, B., Hosseini, M., Dehkordi, H., Asadi, V. (2017). The effects of gibberellic acid on some morpho-physiological characteristics of two varieties of white and yellow flowers (Alba and Apollo) Snapdragon (Antirrhinum majus). Iranian Horticultural Science, 48 (2), 265-273.

[4] Roustaee, AS (Translation). (2002). Les cultures vegetales hors sol. (hydroponics cultivation). Philippe Morard, Jihad Publishing House. 424 pages.

[5] Mortezaei F., Etemadi, N., (2010). Effect of salicylic on growth and flowering of Maryam flower (Pollinates thuberosa L.). Journal of Modern Science of Agriculture, 6(18).

[6] Mansouri M, Shoor M, Tehranifar A, Selahvarzi Y. (2015).Effect of foliar application of salicylic acid and thiamine on quantitative and qualitative characteristics of gerbera (Gerbera jamesonii L. cv. Pink Elegance). Journal of Science and Technology of Greenhouse Culture.; 6 (3), pp.18-22

[7] Arteca, R. N. 1950. Plant growth substances: principles and applications. Springer Science and Business Media.

[8] Cardoso, J. C., Ono, E. O., and Rodrigues, J. D. 2010. Gibberellic acid and water regime in the flowering induction of Brassocattleya and Cattleya hybrid orchids. Horticultura Brasileira, 28(4), 395-398.

[9] Dole J, Wilkins H (12006). Floriculture principles and species. ed. Prentice Hall New Jersey, USA. 465 p. 8.

[10] Dole, J. M.,and Wilkins, H. F. 1999. Floriculture: principles and species. Prentice-Hall Inc.

[11] Jabbarzadeh, Z., Khosh-Khui, M., and Salehi, H. 2009. The effect of foliar-applied salicylic acid on flowering of African violet. Australian Journal of Basic and Applied Sciences, 3(4), 4693-4696.

[12] Martin-Mex, R., Villanueva-Couoh, E., Herrera-Campos, T., and Larque-Saavedra, A. 2005. Positive effect of salicylates on the flowering of African violet. Scientia horticulturae, 103(4), 499-502.

[13] Ramdevputra, M. V., Deshmukh, H. N., Butani, A. M., Savaliya, J. J., Pansuriya, A. G., and Kanzaria, D. R. 2009. Effect of different gibberellic acid (GA3) concentrations on growth, flowering, and yield of African marigold. Asian Journal of Horticulture, 4(1), 82-85. 